\title{
Fibronectin Expression in the Normal and Hypertrophic Rat Heart
}

Wilfred S. Mamuya and Peter Brecher

Department of Biochemistry and Whitaker Cardiovascular Institute, Boston University School of Medicine, Boston, Massachusetts 02118

\begin{abstract}
We examined changes in the expression of fibronectin during the induction of cardiac hypertrophy by L-triiodothyronine administration and by mineralocorticoid- and salt-induced experimental hypertension. By use of Northern and Western blotting procedures, fibronectin was localized mainly in the atria of normal rat hearts. Atria contained 10 - and 5-fold higher relative concentrations of fibronectin mRNA and protein, respectively, compared with ventricles. During the progression of cardiac hypertrophy induced by L-triiodothyronine over a 10-d period, there was a progressive increase in fibronectin mRNA for the first $6 \mathrm{~d}$ followed by a return to control levels. The major change could be accounted for by changes in ventricular mRNA, which increased about four- to sixfold. In contrast, protein levels in ventricles increased progressively over the 10-d treatment period. Ribonuclease protection analysis indicated that the relative amounts of fibronectin isoforms containing exons designated EIIIA and EIIIB increased during the progression of hypertropy. When cardiac hypertrophy was induced by mineralocorticoid and salt treatment, increases in ventricular fibronectin mRNA and protein and the induction of alternatively spliced forms of fibronectin were also observed. However, the extent and temporal pattern of fibronectin expression differed between the two experimental models. (J. Clin. Invest. 1992. 89:392-401.) Key words: triiodothyronine $\bullet$ extracellular matrix • alternate splicing $\bullet$ hypertension $\bullet$ myocytes
\end{abstract}

\section{Introduction}

Fibronectin, a dimeric glycoprotein found in the extracellular matrix of most tissues, is thought to have a functional role in various biological events, including cell adhesion, cell migration, wound repair, and oncogenesis $(1,2)$. The protein is the product of a single gene and is subject to alternate splicing, leading to the formation of different isoforms (3). Fibronectin can bind to other components of the extracellular matrix and to specific receptors on cell membranes, and those interactions can influence either the structural or mechanical properties of the matrix and the phenotype of the adhering cells.

Fibronectin has been identified immunohistochemically in the interstitial tissue of cardiac tissue from young and adult rats and has been shown to be synthesized by neonatal myocytes (4). In the neonatal and normal adult heart, immunodetectable fibronectin is distributed in a reticular pattern, suggesting a

Address correspondence to Peter Brecher, Ph.D., Department of Biochemistry, Boston University School of Medicine, 80 East Concord Street, Boston, MA 02118. 1991.

Received for publication 3 July 1991 and in revised form 26 August

J. Clin. Invest.

(c) The American Society for Clinical Investigation, Inc.

$0021-9738 / 92 / 02 / 0392 / 10 \quad \$ 2.00$

Volume 89, February 1992, 392-401 pericellular or interstitial localization around most cells. Fibronectin has been localized along the outer surface of myocytes and appears to connect the cell to perimyocytic collagen, implying a role for fibronectin in modulating collagen orientation and thereby influencing myocardial compliance (5). Another study has noted that, in the heart, fibronectin is preferentially distributed around vascular tissue (6). Recently, an immunohistochemical study of fibronectin in experimental myocardial infarction showed marked increases in immunodetectable protein in the infarcted area after only 1 to $2 \mathrm{~d}$ after coronary ligation, with the maximum intensity of staining diminishing subsequently (7). The early changes were attributed to plasmaand platelet-derived fibronectin, whereas de novo synthesis, which occurred later, appeared to be the second source of increased fibronectin deposition. Immunohistochemical techniques have also been used to show alterations of extracellular matrix components in the rat heart during acute pressure overload induced by thoracic aortic constriction (6). Fibronectin accumulated in focal areas of damage within $2 \mathrm{~d}$ after surgery, preceding changes in collagen, suggesting that fibronectin was a sensitive marker of cardiac lesions. There appear to be no other prior reports on the relationship between fibronectin expression in cardiac tissue and cardiac hypertrophy, despite the multifunctional properties of fibronectin as an extracellular matrix component and the importance of cardiac hypertrophy in clinical medicine.

We recently found major increases in fibronectin mRNA and protein in the rat aorta after the onset of experimental or genetic hypertension (8), conditions known to induce vascular hypertrophy. Fibronectin has been shown to induce changes in the phenotype of cultured vascular smooth muscle cells that resemble the changes occurring in vivo in response to hypertension (9), suggesting that fibronectin may have a causative role in vascular hypertrophy. In this study we have induced cardiac hypertrophy in rats by either triiodothyronine administration or by a deoxycorticosterone (DOC) ${ }^{1}$ and salt-induced form of experimental hypertension and have measured the changes in cardiac fibronectin. We used Northern blotting procedures to measure steady-state mRNA levels, ribonuclease protection assays to determine changes in alternatively spliced isoforms of fibronectin, and Western blotting techniques to assess directly the amount and nature of the protein present. We found that fibronectin expression increased in both experimental models, but temporal and spatial differences in amounts of steady-state mRNA, alternatively spliced isoforms, and protein were observed between the two models.

\section{Methods}

Materials. Gene Screen membrane, $\left[\alpha_{-}{ }^{32} \mathrm{P}\right] \mathrm{dCTP},\left[\alpha_{-}{ }^{32} \mathrm{P}\right] \mathrm{CTP}$, Econofluor and Protosol (0.5-M solution) were obtained from DuPont/New

1. Abbreviations used in this paper: DOC, deoxycorticosterone acetate; GAPD, glyceraldehyde-3-phosphate dehydrogenase; Pipes, 1,4-piperazine-diethanesulfonic acid. 
England Nuclear Corp. (Boston, MA). In vitro transcription and ribonuclease protection assay kits were purchased from Ambion, Inc. (Austin, TX). Nitrocellulose paper and protein standards for SDS-PAGE were purchased from Bio-Rad Laboratories (Richmond, CA). Polyclonal goat anti-rabbit and goat anti-human fibronectin antibodies were purchased from Sigma Chemical Co. (St. Louis, MO), as was the antigoat IgG-horseradish peroxidose antibodies. MAb against the fibronectin EIIIA exon was a gift from Dr. L. Zardi (Cell Biology Laboratory, Istituto Nazionale per la Ricerca sul Cancro, Genova, Italy).

Animals. Male Wistar rats, $175-200 \mathrm{~g}$, were obtained from Charles River Breeding Laboratories (Wilmington, MA), allowed a 1-2-wk period of adjustment to the animal quarters, and used for all studies described. L-triiodothyronine was administered by intraperitoneal injection at a dosage of $10 \mu \mathrm{g} / 100 \mathrm{~g}$ body wt in a total volume of $0.25 \mathrm{ml}$. Injections were given daily for time periods up to $10 \mathrm{~d}$. Control animals were given equal volumes of saline. DOC and salt hypertension were induced as previously described (10). Briefly, DOC pellets (100 mg s.c.) were implanted into uninephrectomized rats and saline was substituted for drinking water. Systolic blood pressure was measured by tail cuff plethysmography and a photoelectric cell detector as described previously (11). Animals were killed with an overdose of sodium pentobarbital. Hearts were rapidly excised, the pericardium was removed, and atria and ventricles were separated at the atrioventricular sulcus, with workers ensuring that the tissue always was kept moist with cold PBS. When necessary, the ventricular free walls were dissected from the septum, and all the tissues were rinsed free of blood before extraction for either RNA or protein.

RNA isolation and Northern blot analysis. Total RNA from rat tissues was extracted using the guanidinium thiocyanate/cesium chloride centrifugation method (12) with minor modifications. RNA concentration was determined by ultraviolet (UV) spectrophotometry, and 5-20 $\mu \mathrm{g}$ of total RNA was separated using $0.9-1.2 \%$ agarose/1.4 M formaldehyde gel electrophoresis. Equivalent amounts of RNA in each lane were confirmed by visual examination of ribosomal RNA using ethidium bromide staining. The gels were denatured, neutralized, and transferred to nylon membranes (Gene Screen; Du Pont Co.). The membranes were rinsed in $2 \times$ standard saline citrate $(1 \times \mathrm{SSC}$ is $0.15 \mathrm{M}$ $\mathrm{NaCl}, 15 \mathrm{mM}$ sodium citrate, $\mathrm{pH}$ 7.4) and UV-crosslinked using a Stratalinker apparatus (Stratagene, Inc., La Jolla, CA). The membranes were prehybridized for $3 \mathrm{~h}$ in $5 \times$ SSC containing $1.5 \%$ SDS, $10 \%$ dextran sulfate, and $200 \mu \mathrm{g} / \mathrm{ml}$ of sonicated salmon sperm DNA. cDNA probes were labeled using the random hexanucleotide primed method (13), with resulting specific activities of $\sim 1 \times 10^{9} \mathrm{cpm} / \mu \mathrm{g}$ DNA. Hybridizations were performed for $16 \mathrm{~h}$ at $60-65^{\circ} \mathrm{C}$ using the prehybridization solution containing labeled probe. The membrane was then washed in $2 \times \mathrm{SSC}$ at ambient temperature for $10 \mathrm{~min}$ and then washed again with $0.5 \% \mathrm{SDS}$ in $0.5 \times \mathrm{SSC}$ at $55^{\circ} \mathrm{C}$ for $30 \mathrm{~min}$. When necessary, a more stringent wash was performed using $0.1 \%$ SDS in $0.1 \times$ SSC at $63^{\circ} \mathrm{C}$ for $10-30 \mathrm{~min}$. The membranes were exposed to preflashed $\mathrm{x}$-ray films (Kodak X-Omat) using intensifying screens (Cronex lightning plus) for $12-36 \mathrm{~h}$ at $-70^{\circ} \mathrm{C}$. Laser densitometry, using a $300-\mathrm{A}$ computing densitometer (Molecular Dynamics, Sunnyvale, CA), was used to quantitate the relative signal intensity of the bands obtained.

Western blot analysis. Tissue samples were homogenized in the cold using a Polytron apparatus in PBS containing aprotinin (5 trypsin inhibitory units $/ \mathrm{ml})$, leupeptin $(10 \mathrm{mM})$, pepstatin $\mathrm{A}(1 \mathrm{mM})$, and PMSF ( $1 \mathrm{mM})$, at a 10:1 ratio of buffer volume to tissue wet weight. The homogenate was centrifuged at $25,000 \mathrm{~g}$ for $20 \mathrm{~min}$ at $4^{\circ} \mathrm{C}$, and the supernatant was removed and saved. The pellet was resuspended in $4 \%$ SDS, the resuspension was heated at $100^{\circ} \mathrm{C}$ for $4 \mathrm{~min}$, and then it was centrifuged at $12,000 \mathrm{~g}$ for $5 \mathrm{~min}$ at room temperature. The supernatant, designated as the SDS extract, was removed and saved. All samples were stored at $-70^{\circ} \mathrm{C}$. Protein concentrations were obtained by use of the BCA Protein Assay Reagent kit supplied by Pierce Chemical Co. (Rockford, IL). Proteins were analyzed by SDS-PAGE as described by Laemmli (14) using a Bio-Rad Mini-Protean II Dual Slab Cell apparatus. Transfer onto nitrocellulose was done using a Trans Blot apparatus (Bio-Rad) at $4^{\circ} \mathrm{C}$ for $14 \mathrm{~h}$ at $120-150 \mathrm{~mA}$ in $20 \mathrm{mM}$ Tris and 200
$\mathrm{mM}$ glycine ( $\mathrm{pH}$ 8.3). Immunodetection was performed with using a goat anti-rabbit polyclonal antibody to fibronectin after pretreatment of the nitrocellulose support with $10 \%$ Carnation evaporated milk for 1 h. Subsequent analysis utilized an anti-goat IgG HRP-conjugated second antibody, and chemiluminescence emitted from luminol oxidized by peroxidase was used as a detection method. The first antibody was used at a dilution of 1:2,500 and the second antibody at a 1:10,000 dilution. The general protocol was similar to that described in the instructions of the Enhanced Chemiluminescence Detection kit obtained from Amersham International (Amersham, UK).

Ribonuclease protection assay. The general procedure followed was that outlined in the instruction supplied with kits obtained from Ambion. Linearized pGEM vectors containing the appropriate cDNA were used as templates to make labeled antisense RNA probes. The transcription reaction was performed using T7 RNA polymerase, $[\alpha-$ ${ }^{32} \mathrm{PJCTP}(800 \mathrm{Ci} / \mathrm{mmol}$, Dupont/New England Nuclear), and unlabeled nucleotides. Each cRNA probe contained regions encompassing alternatively spliced exons and adjacent exons common to all forms of fibronectin. The labeled RNA probes $\left(0.5-1.5 \times 10^{5} \mathrm{cpm} ; 300-900 \mathrm{pg}\right)$ were precipitated together with 5-10 $\mu \mathrm{g}$ of total RNA from the designated tissue source. The RNA mixture was resuspended in a hybridization solution containing $80 \%$ formamide, $40 \mathrm{mM}$ 1,4-piperazine-diethanesulfonic acid (Pipes, pH 6.4), $400 \mathrm{mM}$ sodium acetate, and $1 \mathrm{mM}$ EDTA. The reaction mixture was heated at $90^{\circ} \mathrm{C}$ for $4 \mathrm{~min}$ and incubations were performed at $45^{\circ} \mathrm{C}$ for $16 \mathrm{~h}$. Excess unhybridized probe was digested with a mixture of RNase T1 (65 U) and RNase A ( $0.33 \mathrm{U})$ in $10 \mathrm{mM}$ Tris, pH 7.5, $300 \mathrm{mM} \mathrm{NaCl}$, and $5 \mathrm{mM}$ EDTA for $30 \mathrm{~min}$ at $37^{\circ} \mathrm{C}$. Yeast RNA $(20 \mu \mathrm{g})$ was added and the samples were treated with $20 \mu \mathrm{g}$ proteinase $\mathrm{K}$ and $1 \%$ SDS for $15 \mathrm{~min}$ at $37^{\circ} \mathrm{C}$ to remove nucleases. The mixture was extracted with phenol/chloroform/isoamyl alcohol and the RNA was precipitated with ethanol. The pellet was resuspended in RNA loading buffer, denatured at $90^{\circ} \mathrm{C}$ for $4 \mathrm{~min}$, and rapidly applied to $5-8 \%$ sequencing gels. After electrophoresis the gel was fixed, dried, and exposed to x-ray film. The autoradiogram was scanned by laser densitometry to quantitate the protected labeled RNA. The radioactive bands corresponding to protected fragments were excised from the dried gel using the autoradiograph as a reference. The gel was rehydrated with $50 \mu \mathrm{l}$ of distilled water and incubated with $10 \mathrm{ml}$ of $5 \%$ Protosol in Econofluor (Du Pont Co.) at $37^{\circ} \mathrm{C}$ for $18 \mathrm{~h}$ before scintillation counting. The relative amounts of fibronectin containing a particular isoform were calculated as follows: protected mRNA fragments that contained EIIIA (280 nt) and EIIIB (350 nt) exons were larger than protected fragments that lacked EIIIA (109 nt) and EIIIB (100 nt). The quantitated amounts of protected fragments lacking the alternatively spliced exons were corrected to take into account the size difference, with the assumption that an equal rate and extent of label incorporation occurred for all protected fragments. The amount of total detectable fibronectin mRNA was the sum of the amounts of both protected fragments, and the relative amounts were computed by dividing the amount of the exon-positive moiety by the total amount of fibronectin mRNA.

cDNA probes. Rat fibronectin ( $\lambda$ rlf-1), prFN-A, prFN-B, and prFN$\mathrm{V}$ were obtained from $\mathrm{R}$. $\mathrm{O}$. Hynes $(3,15)$. Human $\beta 1$ integrin and glyceraldehyde 3-phosphate dehydrogenase were purchased from American Type Culture Collection (Rockville, MD). Rat collagen type I $\alpha 1$ and $\alpha 2$ chains (palR1 and pa2R2) were obtained from D. Rowe (16). A 330-bp HincII-EcoRV fragment (pDT 1505) for mouse type III collagen was a gift from B. Crombrugghe (University of Texas).

\section{Results}

Northern blot analysis was performed on total RNA obtained from anatomically different regions of the rat heart (Fig. $1 \mathrm{~A}$ ). Steady-state mRNA levels for cardiac fibronectin were considerably greater in the atria than ventricles, with no marked differences between the left and right atria or between left ventricle, right ventricle, or septum. Atrial tissue contained 10-fold 


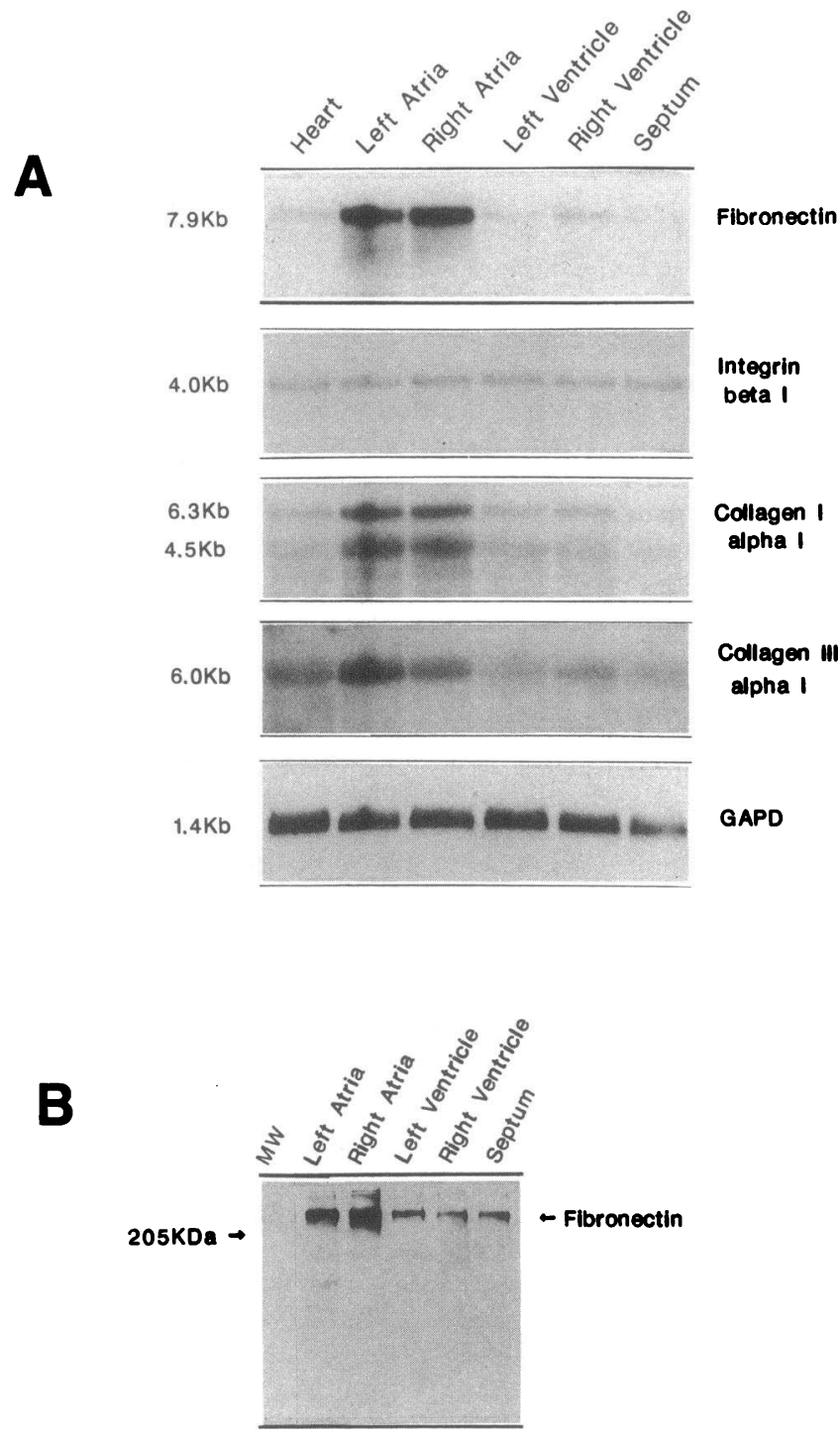

Figure 1. Northern and Western blot analysis of cardiac RNA from Wistar rats. $(A)$ Each lane contains $20 \mu \mathrm{g}$ of total RNA obtained from the designated region of the rat heart. The same nylon membrane was rehybridized for each of the five different probes used. $(B)$ Each lane contains $40 \mu \mathrm{g}$ of protein from the SDS extract of homogenates prepared from the designated region of the heart. Immunodetection was performed using a goat anti-rabbit polyclonal antibody to fibronectin as a first antibody and chemiluminescence emitted from oxidized luminol as the detection method.

more fibronectin mRNA than ventricular tissue, as measured by densitometry using six separate comparisons from different animal pools. The levels of fibronectin mRNA in whole heart were reflective of the amounts found in ventricles, which comprise most of the cardiac mass. Analysis of mRNA for both the $\alpha 1$ chains of collagen type I and III, which represent the most abundant forms of collagen in the extracellular matrix of cardiac tissue, also showed major differences in distribution between atrial and ventricular segments, the differences paralleling those found with fibronectin, with the atria containing twoto fourfold more collagen mRNA than ventricles. We also analyzed mRNA levels for the $\beta 1$ subunit of the integrin family, which is known to be a component of an integrin receptor that binds to both fibronectin and collagen (17). Interestingly, the distribution of the $\beta 1$ integrin mRNA was similar both in atria and ventricles, as were the mRNA levels for glyceraldehyde-3phosphate dehydrogenase (GAPD), which was included as an example of a constitutively expressed gene.

Western blot analysis for fibronectin was performed on cardiac tissue samples to determine the relationship between changes in mRNA and protein. By use of methodology developed previously to measure fibronectin in the aorta (8), tissue samples were homogenized and centrifuged, and the pellet was extracted with $4 \%$ SDS. Fig. $1 B$ shows the distribution of immunoreactive fibronectin in the SDS extracts from atrial and ventricular tissue. There was four to fivefold more fibronectin in atrial samples than ventricles and little detectable difference between the left and right segments of the heart. These findings were in good agreement with data from Northern blot analysis, consistent with transcriptional events having a role in influencing the amounts of tissue fibronectin.

Cardiac hypertrophy was induced by the administration of triiodothyronine over a $10-\mathrm{d}$ period, and changes in steadystate mRNA levels for fibronectin were determined. Table I summarizes the changes observed in cardiac weight and blood pressure for 43 animals used for the thyroxine studies. Heart weight was increased in response to hormone injection, consistent with previous data showing triiodothyronine rapidly induces cardiac hypertrophy $(18,19)$. Body weight increases over the 10-d treatment period were comparable in control and treated animals, and weight losses did not occur. Systolic blood pressures in the treated animals were elevated to levels consistent with moderate hypertension $(150-160 \mathrm{mmHg})$.

Fig. 2 shows representative Northern blot analysis for fibronectin mRNA in ventricular and atrial tissue from control and triiodothyronine-treated rats. There was a significant increase in steady-state mRNA levels of fibronectin in both the left and right ventricles after only $3 \mathrm{~d}$ of treatment. This increase persisted throughout the day 6 and then decreased between 6 and $10 \mathrm{~d}$. A similar pattern of change in steady-state mRNA was observed for $\beta 1$ integrin in the ventricles, whereas no change was obvious for GAPD. Quantitative densitometric analysis of the mRNA was expressed as a ratio of fibronectin to GAPD for each RNA sample; the data indicated a fourfold increase in left ventricular free wall and a sixfold increase in right ventricular free wall fibronectin mRNA between 3 and $6 \mathrm{~d}$ of treatment, followed by a return to control levels. Analysis of the changes for the $\beta 1$ integrin subunit mRNA relative to the GAPD signal

Table I. Effect of Thyroid Hormone(T3) Treatment on Wistar Rats

\begin{tabular}{lccccc}
\hline Treatment & Time & $n$ & $\begin{array}{c}\text { Blood } \\
\text { pressure }\end{array}$ & Heart weight & $\begin{array}{c}\text { Heart wt/ } \\
\text { body wt }\end{array}$ \\
& $d$ & & $m m H g$ & $g$ & $\times 10^{3}$ \\
Control & $3-10$ & 12 & $128 \pm 5$ & $0.93 \pm 0.04$ & $3.60 \pm 0.2$ \\
T3 & 3 & 6 & $161 \pm 9$ & $1.11 \pm 0.04$ & $4.50 \pm 0.1$ \\
T3 & 5 & 7 & $153 \pm 5$ & $1.11 \pm 0.02$ & $4.36 \pm 0.1$ \\
T3 & 6 & 6 & $147 \pm 7$ & $1.09 \pm 0.04$ & $4.44 \pm 0.1$ \\
T3 & 10 & 12 & $167 \pm 5$ & $1.20 \pm 0.03$ & $4.42 \pm 0.1$ \\
& & & & &
\end{tabular}

Data are expressed as means \pm SEM. Triiodothyronine (T3) was administered intraperitoneally at a dosage of $10 \mu \mathrm{g} / 100 \mathrm{~g}$ body wt. Statistical significance was analyzed using a one-way analysis of variance followed by a Student-Newman-Keuls test, and all treatment groups differed significantly from controls $(P<0.05)$. $n$, number of animals in each group. 


\section{A}

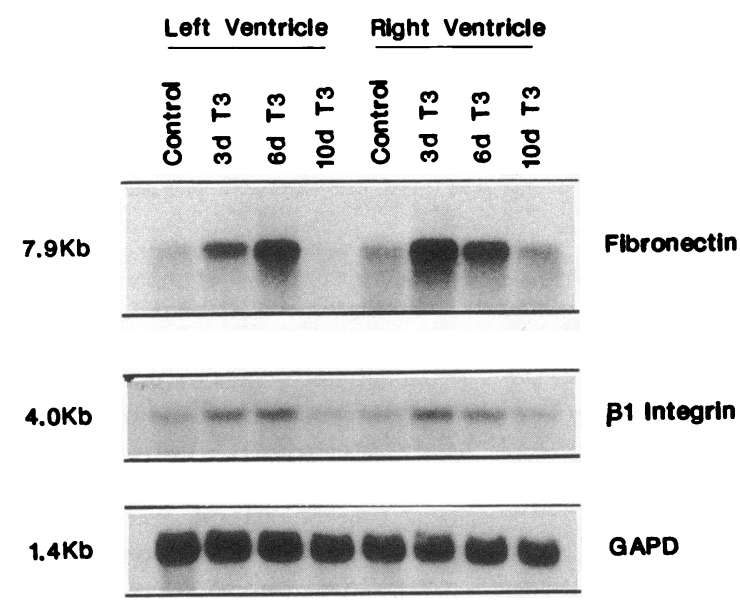

B

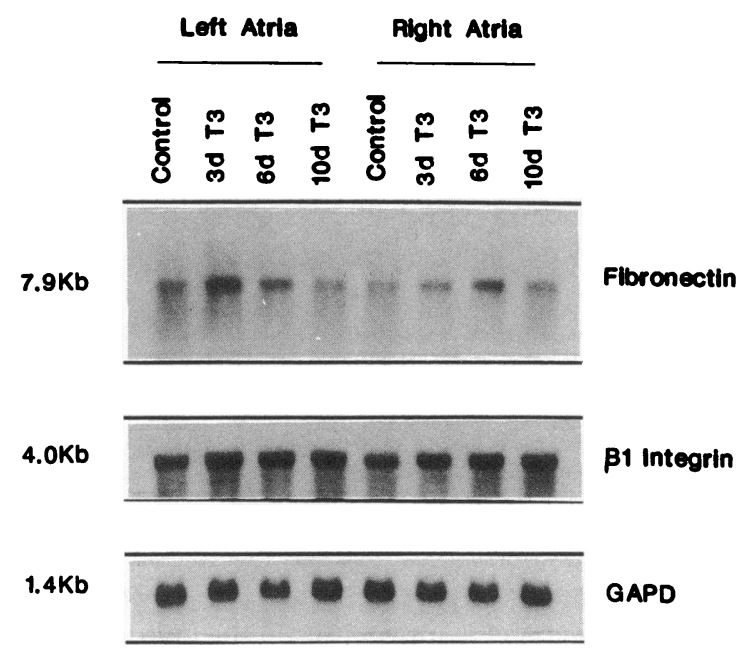

Figure 2. The effect of triiodothyronine (T3) treatment on steadystate mRNA levels of fibronectin, $\beta 1$-integrin, and GAPD in rat atria and ventricles. Northern blot analysis was performed using total RNA obtained from heart of rats treated with triiodothyronine for the designated time. The nylon membranes used in Fig. 3, $A$ and $B$ were rehybridized for each of the three different probes used. $(A)$ Each lane contains $20 \mu \mathrm{g}$ of total RNA isolated from ventricles of five or six rats. The control lane contains $20 \mu \mathrm{g}$ of total RNA from ventricles of six control animals, killed at different times during the treatment period. $(B)$ Each lane contained $10 \mu \mathrm{g}$ of total RNA from the atria of five or six rats, and the control lanes contained $10 \mu \mathrm{g}$ of total RNA from the atria of six animals killed at different time intervals during the course of treatment.

indicated about a twofold increase over control levels after 3 and $6 \mathrm{~d}$ before returning to control levels by day 10 , a pattern analogous to that for fibronectin mRNA. There were no measurable changes in fibronectin expression in control animals over the $10-\mathrm{d}$ period.

Changes in atrial tissue were less pronounced than those observed in the ventricles. There was an increase in atrial fibronectin mRNA between 3 and $6 \mathrm{~d}$ of drug treatment (Fig. $2 \mathrm{~B}$ ), but the changes were visibly less than those seen in ventricles; and when quantitation was performed and expressed relative to the unchanged amounts of atrial GAPD, there was a 1.5-2fold increase during this period. $\beta 1$ integrin mRNA increased $\sim 1$.5-fold and exhibited a similar pattern. Similar changes were observed for both atria and ventricles when the entire treatment protocol was repeated with animals being killed after 5 and $10 \mathrm{~d}$ of treatment (data not shown).

Western blot analysis of ventricular tissue after triiodothyronine administration showed a progressive increase in ventricular fibronectin during the 10-d treatment period (Fig. $3 A$ ). Densitometric quantitation indicated that the amount of protein had increased by 2 -fold after $5 \mathrm{~d}$ and by 3.5 -fold after $10 \mathrm{~d}$ of treatment. This was in contrast to the Northern blot analysis data, in which transient changes were observed, and there was little difference in steady-state mRNA levels for ventricular fibronectin between control and 10-d-treated animals. Thus, there was a clear dissociation between mRNA and protein expression in this model of cardiac hypertrophy. Fig. $3 B$ is a duplicate gel to that used for Western blotting, and staining with Coomassie blue indicated comparable amounts of protein in all samples with no major differences in the amount or profiles of stainable proteins during the course of treatment.

The availability of specific probes that permit a distinction to be made between alternatively spliced forms of fibronectin made it possible to further characterize fibronectin expression during triiodothyronine treatment using $\mathrm{RNase}$ protection assays. The cRNA probes used for these assays included regions contained within the alternatively spliced exons and also contained adjacent type sequences that were common to all forms

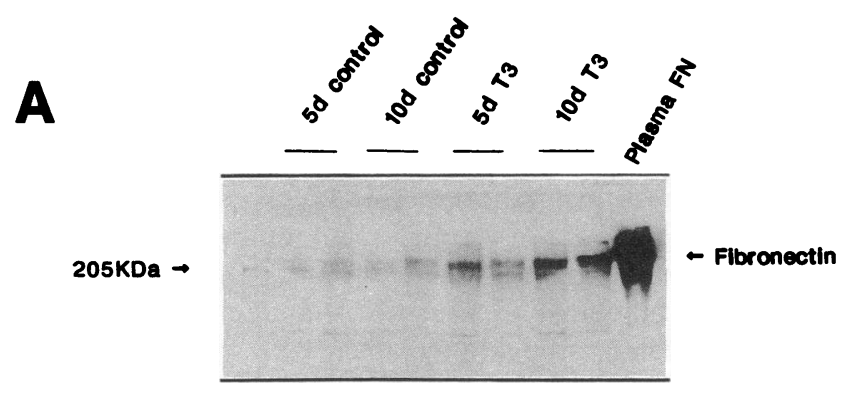

B

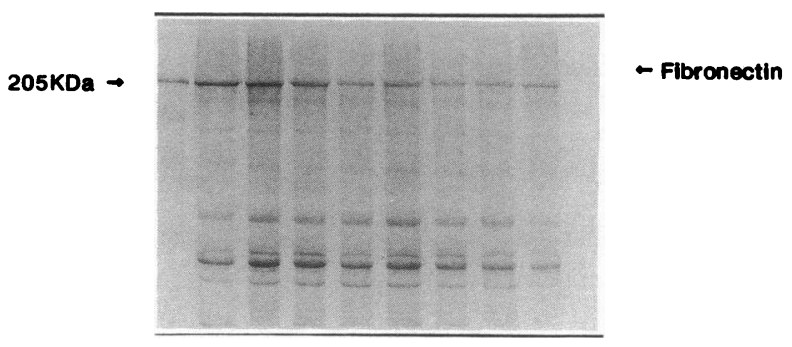

Figure 3. Western blot analysis for ventricular fibronectin from Wistar rats treated with triiodothyronine $(T 3)$. Each lane consists of 20 $\mu \mathrm{g}$ of protein from the SDS extract of homogenates of individual ventricles. Purified plasma fibronectin (100 ng) was used as a reference. $(A)$ Immunodetection was performed using goat anti-rabbit polyclonal antibody to fibronectin as a first antibody. (B) A duplicate gel was stained with Coomassie blue to visualize the amounts and protein profile. 

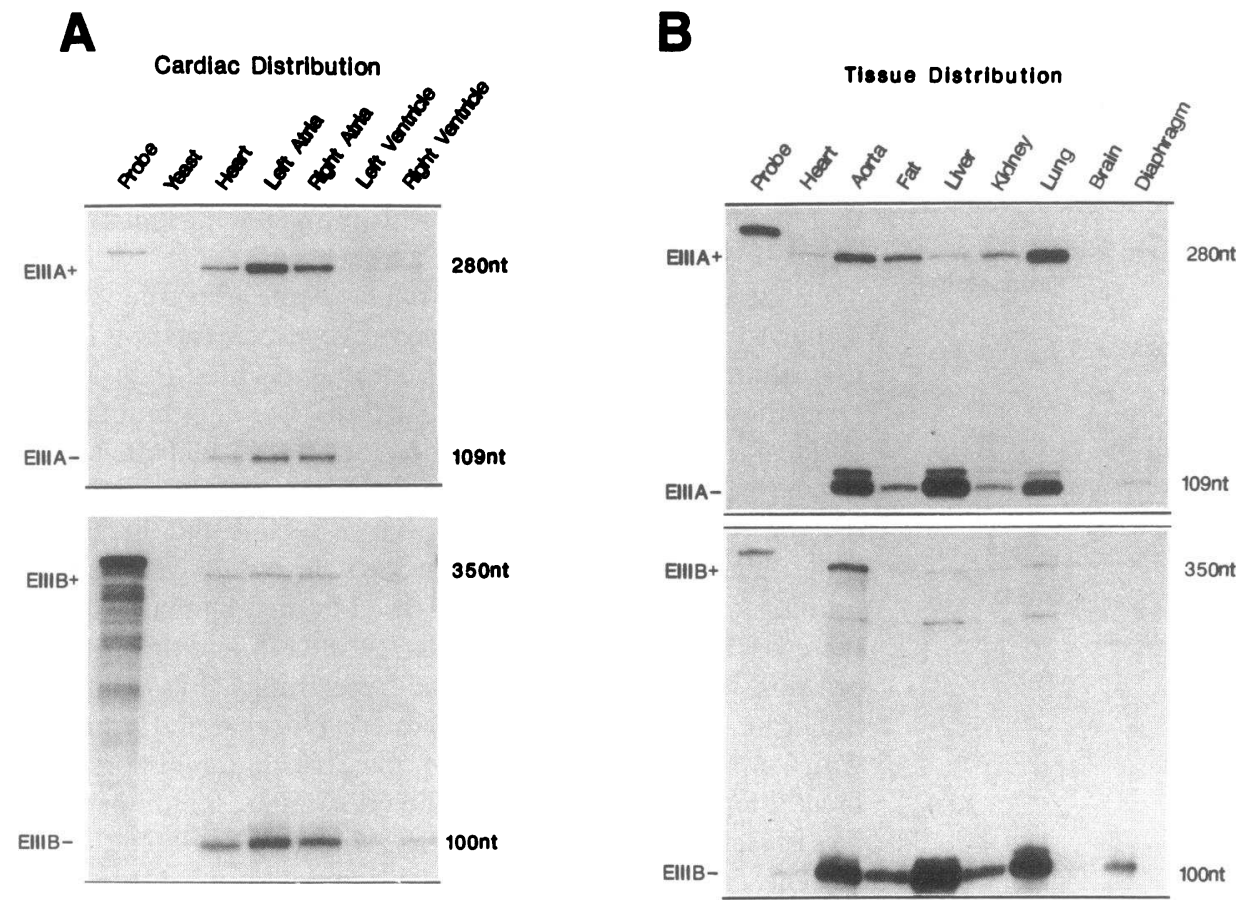

Figure 4. EIIIB-containing mRNA isoforms in rat tissues. Each lane contained $10 \mu \mathrm{g}$ of total RNA from the designated source. For each assay, 10 $\mu \mathrm{g}$ of yeast RNA also was included as an additional control. $(A)(T o p)$ Cardiac distribution of fibronectin mRNA containing or lacking the EIIIA exon. (Bottom) Cardiac distribution of fibronectin mRNA containing or lacking the EIIIB exon. $(B)$ (Top) Tissue distribution of fibronectin containing or lacking the EIIIA exon. (Bottom) Tissue distribution of fibronectin mRNA containing or lacking the EIIIB exon.

of fibronectin. Thus, it was possible to estimate the amount of fibronectin mRNA containing the exon in question relative to the amount of total fibronectin mRNA (see Methods).

Fig. $4 \mathrm{~A}$ summarizes data on the expression of fibronectin mRNA either lacking or containing the inserts designated EIIIA and EIIIB in both atria and ventricle of control rats. There was uniformly more fibronectin in the atria than ventricle, consistent with Northern blot analysis. Quantitation of the relative amount of EIIIA-containing fibronectin mRNA relative to total detected fibronectin mRNA in the heart indicated that $44 \%$ of the total contained the EIIIA exon. In contrast, cardiac fibronectin containing the EIIIB exon was much less abundant both in atria or ventricles, amounting to only $4 \%$ of the total fibronectin mRNA in all samples analyzed.

Because of the high levels of EIIIA-containing fibronectin mRNA in cardiac tissue and the absence of available data on fibronectin isoform distribution in noncardiac tissues of the rat, we analyzed isoform expression in different tissues of the adult rat by ribonuclease protection assays (Fig. $4 \mathrm{~B}$ ). The tissue comparisons indicate that fibronectin was most abundant in liver, aorta, and lung, with liver mRNA mainly lacking the EIIIA and EIIIB exons, a finding established previously by others $(20,21)$. Cardiac tissue contained relatively small amounts of fibronectin mRNA, as did brain and diaphragm. Quantitation of the data in Fig. 4, combined with analysis of tissue RNA using a probe specific for exon V (data not shown), permitted an expression of the relative distribution of alternatively spliced exons in the different tissues (Table II). Cardiac tissue contained the highest amounts of EIIIA-containing fibronectin mRNA (44\%) and liver the least (2\%). The distribution of EIIIB-containing fibronectin mRNA was low in all tissues, including the heart, and did not exceed $10 \%$ of the total fibronectin, whereas the $\mathrm{V}$ exon was found in all samples at levels approximating $50 \%$ of total fibronectin mRNA detected.

RNase protection assays were also performed on samples from triiodothyronine-treated animals (Fig. 5). The samples used in the RNase protection assays were pooled from five or six different animals and thus represent a mean value for that treatment timepoint. Consistent with the findings from Northern blot analysis, left ventricular RNA samples contained more fibronectin mRNA for all forms of fibronectin between days 3 and 6 of treatment (Fig. $5 \mathrm{~A}$ ). Densitometric analysis indicated that EIIIA-containing fibronectin mRNA had increased after 3 d (2.5-fold over control), whereas fibronectin mRNA lacking the EIIIA insert was most abundant at day 6 (2.5-3-fold). As a consequence, the relative amount of EIIIA-containing mRNA was maximal after $3 \mathrm{~d}$ of treatment $(60 \%)$ and subsequently returned to control levels by day 10 . EIIIB-containing mRNA (Fig. $5 A$ ) increased sevenfold after $6 \mathrm{~d}$, with the relative amount increasing to $10 \%$ of total fibronectin mRNA before declining to control amounts by the 10th $\mathrm{d}$. When atrial RNA was analyzed (Fig. 5 B), the relative amount of EIIIA-contain-

Table II. Relative Distribution of Fibronectin mRNA Isoforms in Adult Rat Tissues

\begin{tabular}{|c|c|c|c|c|c|c|c|c|c|}
\hline Isoform & Atria & Ventricle & Aorta & Fat & Liver & Kidney & Lung & Brain & Diaphragm \\
\hline EIIIA & 43 & 44 & 14 & 26 & 2.6 & 22 & 27 & 37 & 8 \\
\hline EIIIB & 4.5 & 4 & 8 & 1.9 & 0.9 & 2.2 & 1.8 & 5.5 & 1.4 \\
\hline V & 57 & 57 & 52 & 57 & 46 & 61 & 48 & 59 & ND \\
\hline
\end{tabular}

Values are percentages of total. ND, not determined. 

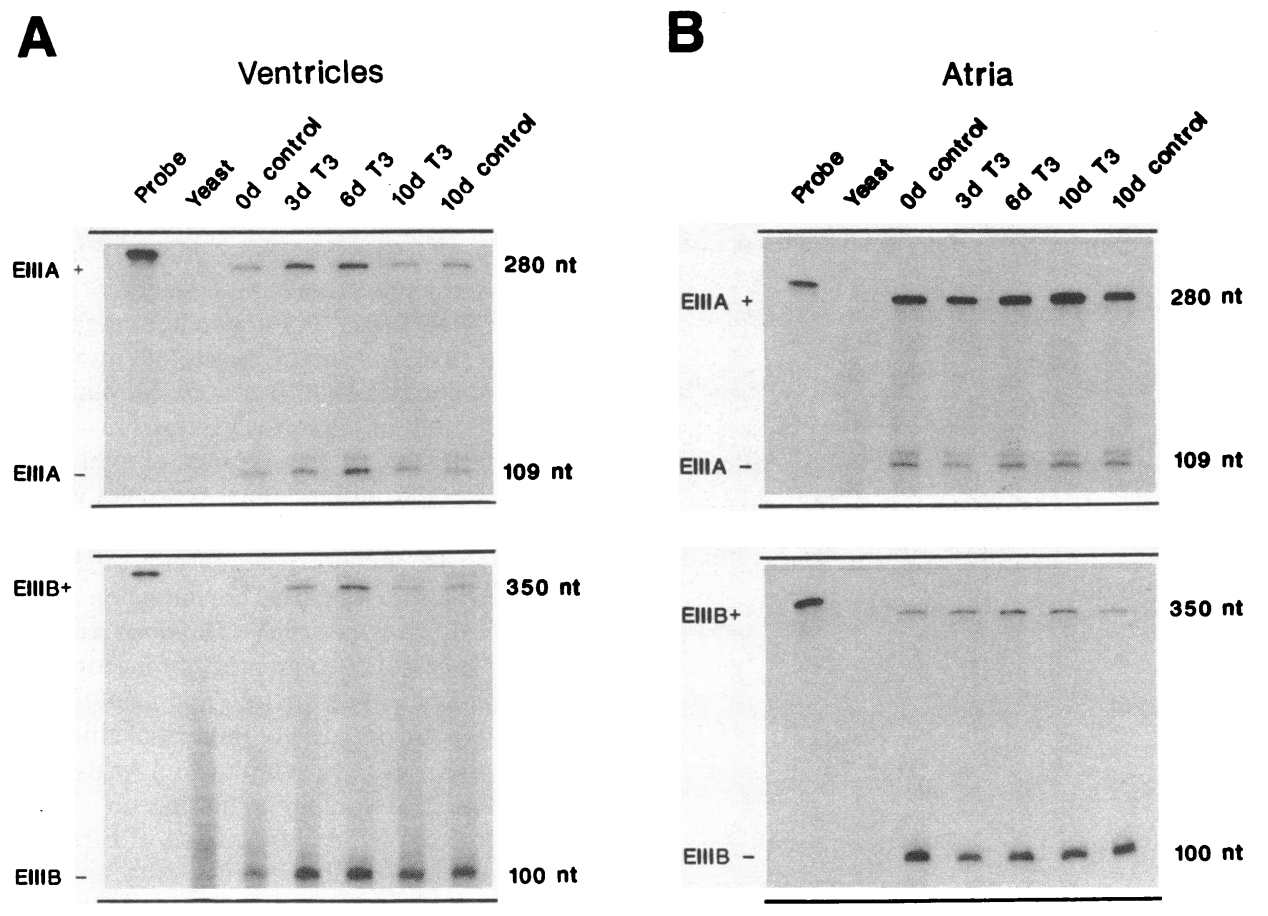

Figure 5. Ribonuclease protection analysis of fibronectin mRNA containing EIIIA and EIIIB exons from atria and ventricles of triiodothyronine (T3)-treated-Wistar rats. $(A)$ Each lane contains $10 \mu \mathrm{g}$ of total left ventricular RNA from a pool of five or six animals. (Top) Analysis of EIIIAcontaining fibronectin $\mathrm{mRNA}$ in ventricles from rats treated with $\mathrm{T} 3$ for the designated time. (Bottom) Analysis of EIIIB-containing fibronectin mRNA. (B) Each lane contains $5 \mu \mathrm{g}$ of total right atrial RNA from a pool of five or six animals treated with T3 for the designated time. (Top) Analysis of EIIIA-containing fibronectin mRNA in atria. (Bottom) Analysis of EIIIB-containing fibronectin mRNA in rat atria during $\mathrm{T} 3$ treatment. Total yeast RNA $(10 \mu \mathrm{g})$ was used as a control for each assay.

ing mRNA increased between the 6th and 10th d, whereas the relative amount of EIIIB-containing mRNA increased slightly after $3 \mathrm{~d}$ and had returned to control levels after $10 \mathrm{~d}$ of triiodothyronine treatment.

Cardiac hypertrophy was also induced in rats by administration of DOC/salt, the hypertrophy presumably resulting from the pressure overload. After 7 and $21 \mathrm{~d}$ of DOC/salt treatment, systolic blood pressure averaged 138 and $183 \mathrm{mmHg}$, respectively, whereas control animals had pressures below 120 $\mathrm{mmHg}$ (Table III). Heart-to-body weight ratios were significantly elevated even after $7 \mathrm{~d}$ of DOC/salt treatment. Fig. 6 shows representative data for ribonuclease protection assays performed using total RNA from cardiac tissue of control and $\mathrm{DOC} /$ salt-treated rats. These assays were repeated using two or three different animals for each time point, and similar results were observed. EIIIA-containing fibronectin mRNA increased 2.5-fold after $7 \mathrm{~d}$ of treatment (Fig. $6 \mathrm{~A}$ ), whereas mRNA lacking EIIIA increased twofold, thereby increasing the relative amount of EIIIA-containing fibronectin mRNA to 55\%. After

Table III. Effect of DOC-Salt Treatment on Wistar Rats

\begin{tabular}{lccccc}
\hline Treatment & Time & $n$ & $\begin{array}{c}\text { Blood } \\
\text { pressure }\end{array}$ & Heart weight & $\begin{array}{c}\text { Heart wt/ } \\
\text { body wt }\end{array}$ \\
& $d$ & & $m m H g$ & $g$ & $\times 10^{3}$ \\
Control & 7 & 6 & $119 \pm 5$ & $0.98 \pm 0.02$ & $3.08 \pm 0.1$ \\
DOC-salt & 7 & 8 & $138 \pm 9$ & $1.12 \pm 0.03^{\ddagger}$ & $3.80 \pm 0.3^{*}$ \\
Control & 21 & 10 & $115 \pm 6$ & $1.11 \pm 0.01$ & $3.11 \pm 0.1$ \\
DOC-salt & 21 & 10 & $183 \pm 7^{\ddagger}$ & $1.32 \pm 0.03^{\ddagger}$ & $4.35 \pm 0.2^{\ddagger}$
\end{tabular}

Animals were treated as described in Methods and the data are expressed as means \pm SEM. Comparisons between age matched groups were made using a two-tailed, unpaired $t$ test. Asterisks indicate that the values are significantly different than age matched controls at a level of ${ }^{*} P<0.05 ;{ }^{\ddagger} P<0.01$. $n$, number of animals.
$21 \mathrm{~d}$, both isoforms had increased about fivefold over control, making the relative amount of EIIIA-containing fibronectin mRNA similar to that of the controls. This was consistent with results obtained during triiodothyronine treatment, in which the relative content of EIIIA-containing fibronectin mRNA increased early during treatment before returning to control levels after $10 \mathrm{~d}$ of thyroxine administration.

No increases in fibronectin mRNA were seen if animals were given DOC alone in the absence of salt addition. Blood pressures also were not increased in these animals either at 7 or $21 \mathrm{~d}$ of treatment; thus, the data suggest that the increases observed with DOC/salt were not due solely to the effects of steroid. The results also are consistent with Northern blot analysis of RNA extracted from whole hearts of DOC/salt-treated animals, where a sixfold increase in fibronectin mRNA level was observed after $21 \mathrm{~d}$ of treatment (data not shown). Ventricular EIIIB-containing fibronectin mRNA showed minor changes after $7 \mathrm{~d}$ but increased eightfold after $21 \mathrm{~d}$ of DOC/salt treatment. Since EIIIB-negative isoforms of fibronectin increased only about four-to fivefold after $21 \mathrm{~d}$, there was an increase in the relative amount of EIIIB-containing isoforms. When RNA from atrial tissue was examined (Fig. $6 \mathrm{~B}$ ), no major changes were seen as a result of DOC/salt treatment for either fibronectin mRNA containing or lacking EIIIA, in marked contrast to ventricular tissue. Protection assays using the probe for EIIIB did indicate a small increase after $7 \mathrm{~d}$ that persisted for $21 \mathrm{~d}$. EIIIB-negative forms did not increase during treatment; thus, the relative amount of EIIIB-containing mRNA increased slightly both in atria and ventricles of the DOC/salt model.

Western blot analysis of tissue extracts from ventricles of DOC/salt-treated animals using a polyclonal antibody directed against plasma fibronectin, which recognizes all forms of fibronectin, showed no measurable increase in fibronectin after $7 \mathrm{~d}$ of treatment (Fig. $7 \mathrm{~A}$ ). Thus, there was a temporal dissociation between changes in steady-state mRNA, which were evident after $7 \mathrm{~d}$ of treatment, and changes in protein levels. However, 


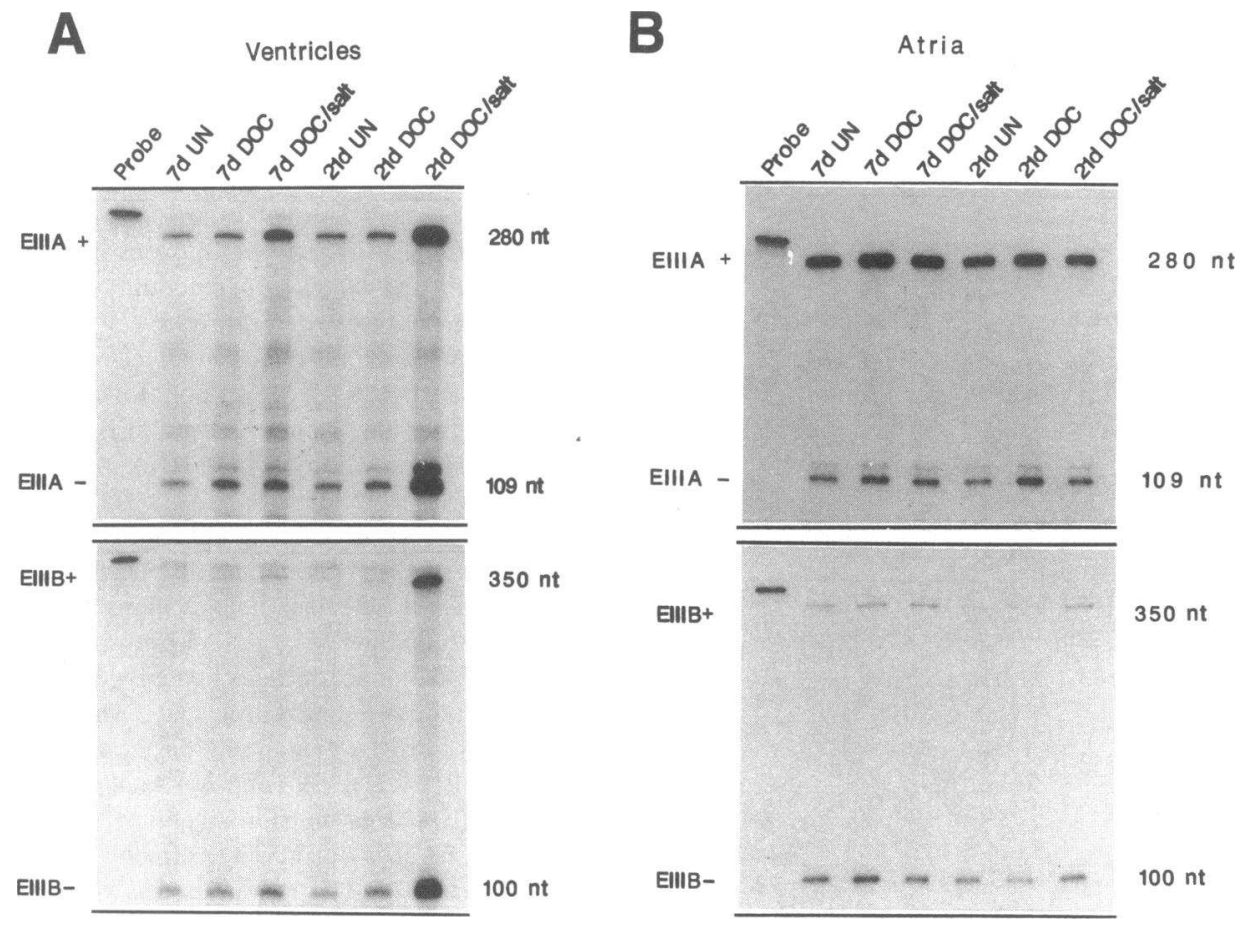

Figure 6. Ribonuclease protection analysis of fibronectin mRNA in atria and ventricles of rats after DOC-saltinduced cardiac hypertrophy. (Control) uninephrectomy alone; (DOC) uninephrectomy, implantation of a DOC pellet, and low-sodium diet; (DOC/salt) uninephrectomy, implantation of a DOC pellet, and administration of $0.9 \% \mathrm{NaCl}$ (saline) in drinking water. $(A) 10 \mu \mathrm{g}$ of total RNA from individual ventricles was used in each lane. (Top) Analysis of EIIIA-containing fibronectin mRNA in ventricles during the induction of cardiac hypertrophy. (Bottom) Analysis of EIIIB-containing fibronectin mRNA in ventricles. $(B) 5 \mu \mathrm{g}$ of total RNA from atria of individual animals was used in each lane. (Top) Analysis of EIIIA-containing fibronectin mRNA. (Bottom) Analysis of EIIIBcontaining fibronectin messages. after $21 \mathrm{~d}$ the fibronectin protein content had increased by sixfold, a finding consistent with changes in steady-state mRNA. Using an MAb directed against the EIIIA-containing region of fibronectin, we detected an increase in immunoreactive protein in response to DOC/salt treatment only after $21 \mathrm{~d}$ (Fig. $7 \mathrm{~B}$ ), indicating that at least part of the increase was cellular in origin.

\section{Discussion}

In this study we have shown a markedly different distribution of fibronectin mRNA and protein in the adult rat heart. Fibro- nectin mRNA and protein were considerably more abundant in atria than in ventricles, with only minor differences between the left and right sides of the heart, demonstrating a good correlation between mRNA levels and levels of expressed protein. Northern blot analysis showed collagen mRNA to be more abundant in atria, consistent with a recent study showing 2-2.5-fold higher amounts of hydroxyproline in atria than ventricle of the adult rabbit heart (22). The disproportionate amounts of fibronectin and collagen in atria could reflect a greater relative number of nonmyocytic fibroblasts in the atria, presumably involved in extracellular matrix production-al-

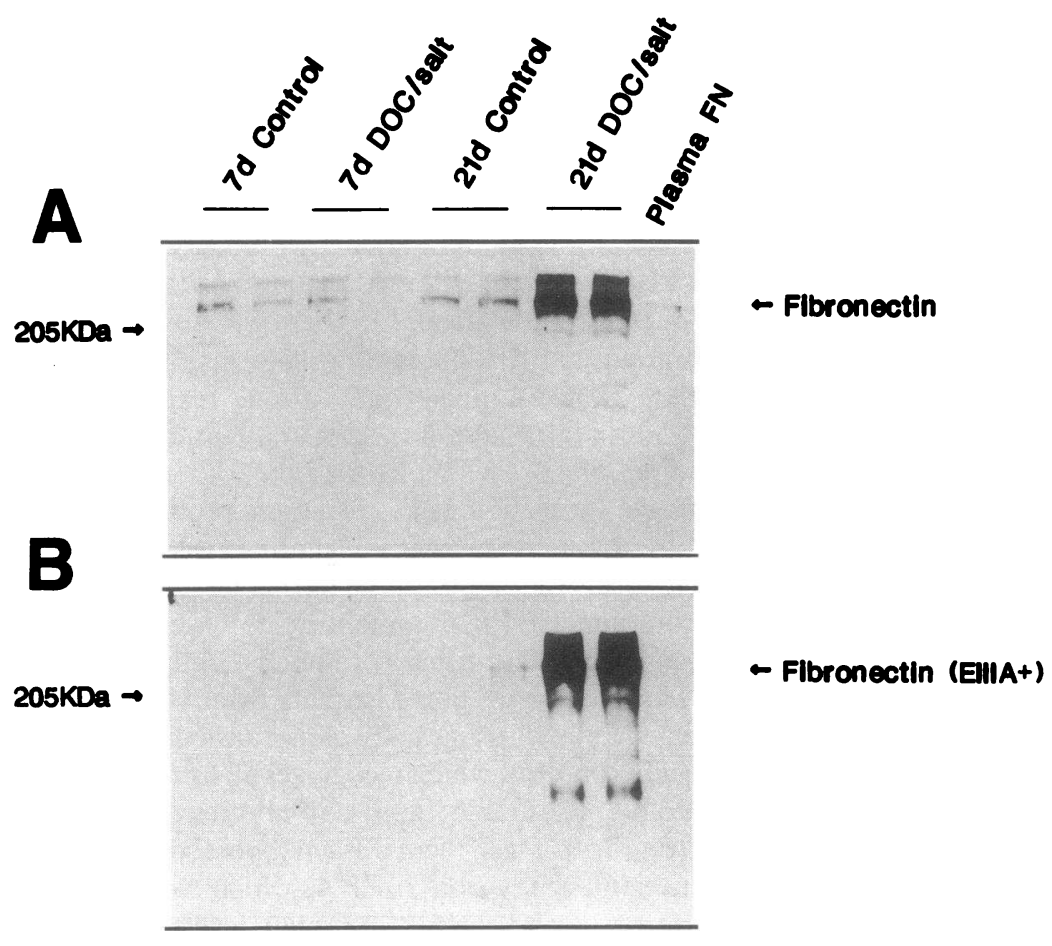

Figure 7. Western blot analysis of ventricular fibronectin from Wistar rats after DOC/salt treatment. Each lane contains $40 \mu \mathrm{g}$ of protein extracted with $4 \%$ SDS from individual ventricles. Purified plasma fibronectin (10 ng) was used as a reference. $(A) \mathrm{Im}$ munodetection using a polyclonal against all forms of the protein was done as previously described. $(B) \mathrm{Im}$ munodetection of fibronectin protein containing the EIIIA exon using a 1:35 dilution of an MAb raised against the protein product of the exon. The specificity of the antibody is demonstrated by the fact that the plasma fibronectin used as a reference was not detected. 
though, interestingly, the mRNA levels for $\beta 1$ integrin, coding for an integrin subunit thought to participate in both fibronectin and collagen-cell interactions, were equally distributed between atria and ventricle. The enhanced expression of fibronectin in atria may also be due to the presence of growth factors such as transforming growth factor- $\beta 1$ and basic fibroblast growth factor (bFGF), known to be present at higher amounts in the atria (23-25), which have been shown to influence the expression of fibronectin and other extracellular matrix proteins.

Fibronectin has been shown to have a critical role during organogenesis of the heart $(26,27)$, and several pathophysiological models have been used to study the expression of fibronectin in the myocardium. After either surgical ventriculotomy (28) or experimental myocardial infarction $(7,29)$, immunohistochemical analysis showed increased fibronectin accumulation within the injured region. An MAb directed against the EIIIA insert was used in one study (29) to permit a histochemical distinction between cellular and circulating fibronectin. An increase in plasma fibronectin was detected early (1-2 d) after the development of experimental myocardial infarction, whereas cellular fibronectin synthesis was detected after $3 \mathrm{~d}$ and had significantly increased after 7-15 $\mathrm{d}$.

This study documents an association between increased fibronectin expression and the development of cardiac hypertrophy. Hypertrophy is a characteristic response of the heart to a sustained increase in workload. Associated with morphological and functional changes, diverse biochemical changes have been studied during the development of cardiac hypertrophy. The changes studied most intensely with respect to hypertrophy include alterations in expression of intracellular proteins, particularly those of the contractile apparatus $(30,31)$, whereas changes in the extracellular matrix have focused largely on collagen (32). In the two models of hypertrophy used in this study, a selective effect on ventricular fibronectin was observed, although distinctions were found in the temporal pattern of mRNA induction and protein expression during the treatment protocols. These observations are reminiscent of the pattern of expression of atrial natriuretic factor, which is expressed primarily in atrial tissue of adult rats but is produced in increased amounts by both ventricles with biventricular hypertrophy (33).

In the only reported study employing an acute model of pressure overload (6), immunofluorescent fibronectin was found $2 \mathrm{~d}$ after surgery in focal areas where myocytes showed signs of necrosis and subsequently accumulated in septa where necrosis was not evident. In contrast to aortic-coarctation or DOC/salt-induced cardiac hypertrophy $(6,34-36)$, the hypertrophy induced by triiodothyronine is known to be biventricular with an absence of obvious myocyte loss, focal necrosis, fibrosis, or other major histological abnormalities $(23,37)$. Triiodothyronine effects on the heart are a result of complex interactions between peripheral and direct effects. The direct effects of the hormone are presumably mediated by a mechanism involving transcriptional activation by the c-erbA protooncogene product $(38,39)$. In one study, a direct transcriptional activation effect on liver fibronectin was observed (40), which may explain the association between thyroid hormone and elevated plasma fibronectin (41).

Myosin heavy chain expression in the heart is influenced by thyroid hormones in rodent models, and a switch between expression of the $\alpha$ and $\beta$ forms of myosin heavy chain only occurs in ventricles when the thyroid status is altered (42). Distinctions in ventricular myosin isozyme patterns between pressure-overloaded and thyroid-induced hypertrophy of rabbit hearts have been described, even for the right ventricle (43), consistent with a specific and probably direct effect of triiodothyronine on cardiac tissue. We observed a rapid induction of fibronectin mRNA after only $3 \mathrm{~d}$ of treatment, but hypertrophy did occur within this time frame, and altered expression of myosin isozymes and other genes $(44,45)$ have been documented several days after alterations in thyroid hormone status.

The transient nature of fibronectin mRNA expression clearly differed from that of immunoreactive protein in the hyperthyroid model during the $10 \mathrm{~d}$ of treatment. It is possible that the turnover of fibronectin is relatively slow in the heart; thus, the progressive increase in immunoreactive protein that we observed could reflect increased synthesis between 3 and $6 \mathrm{~d}$ concomitant with slow or reduced degradation. There is no published information of fibronectin turnover in the heart, but a review of studies in cultured cells has indicated that fibronectin biosynthesis is regulated primarily by transcriptional mechanisms (46). Regardless of whether transcriptional or posttranscriptional mechanisms are involved, there was a clear temporal dissociation between steady-state levels of mRNA and accumulation of immunoreactive proteins in the ventricles for both models used in this study.

Most of the available information on the relative expression of isoforms of fibronectin has been obtained from a variety of cultured cells. Since cultured cells may express isoforms normally not seen in vivo, caution has to be used in interpreting such data. We have compared the amounts of mRNA for three alternatively spliced fibronectin isoforms in the heart and several other tissues of the adult rat. The relative amount of EIIIAcontaining fibronectin isoform was surprisingly high in the heart and brain, although these organs contained a relatively low amount of total fibronectin mRNA compared with other tissues. No specific biological function has been assigned to EIIIA- or EIIIB-containing fibronectin, largely because of difficulties in obtaining purified forms of the different isoforms; however, recent studies with specific isoforms produced by retrovirus infected cells suggested that proteins containing the exons have an improved ability to enhance matrix formation (47).

In both experimental models used in these studies, the relative amount of EIIIA-containing fibronectin mRNA increased slightly during the induction of cardiac hypertrophy and subsequently returned to control levels. The increase in the relative amount of EIIIB was transient in the triiodothyronine-treated animals and was seen only when cardiac hypertrophy was well established in the DOC/salt model. Embryonic isoforms of fibronectin are known to have a high relative content of EIIIAand EIIIB-containing mRNA (48), and increased expression of both isoforms also has been observed in a tissue-specific manner during wound healing and oncogenic transformation (21, 49). Those conditions have in common the proliferation and differentiation of specific cell types, events that also occur during the development of cardiac hypertrophy. Myocardial hypertrophy, whether induced by pressure overload or thyroid hormones, is known to be accompanied by the reexpression of fetal isoforms of genes for myosin heavy chain (50).

Fibronectin expression was increased using two in vivo models of cardiac hypertrophy in this study, and in a previous 
study we showed that fibronectin expression was increased in aortic tissue during the induction of aortic hypertrophy (8). Taken together, these data show an association between cellular hypertrophy and fibronectin induction. In the DOC/salt model, focal scars have been reported to appear in the heart $(35,36)$, and it is possible that the large increase in fibronectin expression we observed was associated with endothelial and fibroblast cell proliferation and infiltration. We noted a large increase in immunoreactive EIIIA-containing fibronectin after $21 \mathrm{~d}$ of treatment, and analogous increases have been characteristic of wound-healing models (29). The DOC/salt model clearly includes pressure overload as a major factor in inducing cardiac hypertrophy, but the endocrine abnormalities and increased presence of plasma catecholamines in this model make the pathophysiology complex. In our studies, we also observed patchy areas of scarring by gross inspection in hearts from animals treated with DOC/salt for $21 \mathrm{~d}$. We confirmed that these regions were fibrotic histologically. No areas of scarring were observed in animals treated for $14 \mathrm{~d}$ or in the animals given triiodothyronine.

It is difficult to determine the relative contribution of the different cell types within the heart to the changes in fibronectin expression caused by triiodothyronine or DOC/salt treatment. Studies with cultured cells have established that nonmyocytic cardiocytes synthesize fibronectin much more actively than cultured neonatal myocytes (4), but studies with cultured cells may not accurately reflect the properties of those cells in the normal heart. The changes seen after treatment with triiodothyronine are less likely to be due to fibroblast proliferation and may reflect a response of cardiac myocytes. Triiodothyronine has recently been shown to regulate the expression of myosin isoforms in cultured cardiac myocytes $(51)$ transfected with the 5 -flanking region of $\alpha$-myosin heavy chain gene, indicating a direct effect of triiodothyronine on cardiac myocytes. Skeletal $\alpha$-actin has been shown to be reinduced in cultured rat cardiac myocytes during adrenergic induction of hypertrophy (52). This shift from cardiac $\alpha$-actin to skeletal $\alpha$-actin in isolated neonatal myocytes reproduced the isoactin switching previously seen in overload-induced hypertrophy of the adult rat heart in vivo (53). Furthermore, the selective changes in actin and myosin isoforms that occur between atria and ventricle in both pressure overload-and triiodothyronine-induced hypertrophy are analogous to the selective changes we observed in fibronectin expression, suggesting the myocyte as a possible target cell. In situ hybridization would be the experimental method of choice to address the issue of cell type response.

Different models of hypertrophy are associated with different intracellular signals generated by various hormones and growth factors. Studies using cultured rat neonatal myocytes have demonstrated that mechanical stretching can directly regulate gene transcription without the participation of humoral factors in cardiocytes (54). Transforming growth factor- $\beta$ has been shown to influence fibronectin expression in several cell types and is thought to regulate extracellular matrix components during several models of injury, including wound repair (55) and postischemic events in the myocardium (25). However, studies using various cell types have shown that fibronectin can be influenced by many regulatory substances, including epidermal and platelet-derived growth factors, glucocorticoids, and CAMP $(56,57)$; and it seems likely that a multifunctional protein such as fibronectin would be under complex regulation during cardiac hypertrophy.

\section{Acknowledgments}

The authors are grateful for the expert technical assistance of Elizabeth H. Eastman, Cynthia Nickerson, Robin Drago, and Susan Hope.

This work was supported by National Institutes of Health grants HL-31 195 and HL-18318. W. S. Mamuya was a Howard Hughes Medical Institute predoctoral fellow.

\section{References}

1. Mosher, D. F. 1989. In Fibronectin. Academic Press, San Diego, CA. 4849.

2. Hynes, R. O. 1990. In Fibronectins. Springer-Verlag, New York. 1-6.

3. Schwarzbauer, J. E., J. W. Tamkum, I. R. Lemischka, and R. O. Hynes. 1983. Three different fibronectin $\mathrm{mRNAs}$ arise by alternative splicing within the coding region. Cell. $35: 421-431$.

4. Ahumada, G. G., S. I. Rennard, A. A. Alvaro, and M. H. Silver. 1981. Cardiac fibronectin: developmental distribution and quantitative comparison of possible sites of synthesis. J. Mol. Cell. Cardiol. 13:667-678.

5. Ahumada, G. G., and J. E. Saffitz. 1984. Fibronectin in rat heart: a link between cardiac myocytes and collagen. J. Histochem. Cytochem. 32:383-388.

6. Contard, F., V. Koteliansky, F. Marotte, I. Dubus, L. Rappaport, and J. L. Samuel. 1991. Specific alterations in the distribution of extracellular matrix components within rat myocardium during the development of pressure overload. Lab. Invest. 64:65-75.

7. Casscells, W., H. Kimura, J. A. Sanchez, Zu-Xi. Yu, and V. J. Ferrans. 1990. Immunohistochemical study of fibronectin in experimental myocardial infarction. Am. J. Pathol. 137:801-810.

8. Takasaki, I., A. V. Chobanian, R. Sarzani, and P. Brecher. 1990. Effect of hypertension on fibronectin expression in rat aorta. J. Biol. Chem. 265:2193521939.

9. Hedin, U., B. A. Bottger, E. Forsberg, S. Johansson, and J. Thyberg. 1988. Diverse effects of fibronectin and laminin on phenotypic properties of cultured smooth muscle cells. J. Cell Biol. 107:307-319.

10. Sarzani, R., P. Brecher, and A. V. Chobanian. 1989. Growth factor expression in aorta of normotensive and hypertensive rats. J. Clin. Invest. 83:14041408 .

11. Haudenschild, C. C., M. F. Prescott, and A. V. Chobanian. 1980. Effects of hypertension and its reversal on aortic intima lesions of the rat. Hypertension. 2:33-44.

12. Chirgwin, J. M., A. E. Przybyla, R. J. MacDonald, and W. J. Rutter. 1979. Isolation of biologically active ribonucleic acid from sources enriched in ribonuclease. Biochemistry 18:5294-5299.

13. Feinberg, A. P., and B. Vogelstein. 1984. A technique for radiolabeling DNA restriction endonuclease fragments to high specific activity. Anal. Biochem. 137:266-267.

14. Laemmli, U. K. 1970. Cleavage of structural proteins during assembly of the head of bacteriophage T4. Nature (Lond.). 227:680-685.

15. Schwarzbauer, J. E., R. S. Patel, D. Fonda, and R. O. Hynes. 1987. Multiple sites of alternative splicing of the fibronectin gene transcript. EMBO (Eur. Mol. Biol. Organ.) J. 6:2573-2580.

16. Genovese, C., D. Rowe, and B. Kream. 1984. Construction of DNA sequences complementary to rat $\alpha 1$ and $\alpha 2$ collagen mRNA and their use in studying the regulation of type I collagen synthesis by 1,25-dihydroxyvitamin D. Biochemistry. 23:6210-6216.

17. Ruoslahti, E. 1991. Integrins. J. Clin. Invest. 87:1-5.

18. Klaubert, A., and J. Zähringer. 1982. The effect of triiodothyronine on cardiac mRNA. J. Mol. Cell. Cardiol. 14:559-571.

19. Morkin, E., I. L. Flink, and S. Goldman. 1983. Biochemical and physiological effects of thyroid hormone on cardiac performance. Prog. Cardiovasc. Dis. 25:435-464.

20. Gutman, A., and A. R. Kornblihtt. 1987. Identification of a third region of cell-specific alternative splicing in human fibronectin mRNA. Proc. Natl. Acad. Sci. USA 84:7179-7182.

21. Oyama, F., S. Hirohashi, Y. Shimosato, K. Titani, and K. Sekiguchi. 1989. Deregulation of alternative splicing of fibronectin pre-mRNA in malignant human liver tumors. J. Biol. Chem. 264:10331-10334.

22. Imataka, K., S. Naito, Y. Seko, and J. Fujii. 1989. Hydroxyproline in all parts of rabbit heart in hypertension and its reversal. J. Mol. Cell. Cardiol. 21:133-139.

23. Kardami, E., and R. R. Fandrich. 1989. Basic fibroblast growth factor in atria and ventricle of the vertebrate heart. J. Cell Biol. 109:1865-1875.

24. Thompson, N. L., K. C. Flanders, J. M. Smith, L. R. Ellingsworth, A. B. Roberts, and M. B. Sporn. 1989. Expression of transforming growth factor- $\beta 1$ in specific cells and tissues of adult and neonatal mice. J. Cell Biol. 108:661-669.

25. Thompson, N. L., F. Bazoberry, E. H. Speir, W. Casscells, V. J. Ferrans, K. C. Flanders, P. Kondaiah, A. G. Geiser, and M. B. Sporn. 1990. Transforming growth factor beta-1 in acute myocardial infarction in rats. Growth Factors. 1:9199. 
26. Mjaatvedt, C. H., R. C. Lepera, and R. R. Markwald. 1987. Myocardial specificity for initiating endothelial-mesenchymal cell transition in embryonic chick heart correlates with a particulate distribution of fibronectin. Dev. Biol. 119:59-67.

27. Linask, K. K., and J. W. Lash. 1988. A role of fibronectin in migration of avian precardial cells. I. Dose-dependent effects of fibronectin antibody. Dev. Biol. 129:315-323.

28. Kawahara, E., A. Mukai, Y. Oda, I. Nakanishi, and T. Iwa. 1990. Left ventriculotomy of the heart: tissue repair and localization of collagen types I, II, III, IV, V, VI and fibronectin. Virchows Arch. A Pathol. Anat. 417:229-236.

29. Shekhonin, B. V., S. B. Guriev, S. B. Irgashev, and V. E. Koteliansky. 1990. Immunofluorescent identification of fibronectin and fibrinogen/fibrin in experimental myocardial infarction. J. Mol. Cell. Cardiol. 22:533-541.

30. Swynghedauw, B. 1986. Developmental and functional adaptation of contractile proteins in cardiac and skeletal muscles. Physiol. Rev. 66:710-771.

31. Nadal-Ginard, B., and V. Mahdavi. 1989. Molecular basis of cardiac performance. J. Clin. Invest. 84:1693-1700.

32. Weber, K. T. 1989. Cardiac interstitium in health and disease: the fibrillar collagen network. J. Am. Coll. Cardiol. 13:1637-1652.

33. Lee, R. T., K. D. Bloch, J. M. Pfeffer, M. A. Pfeffer, E. J. Neer, and C. E. Seidman. 1988. Atrial natriuretic factor gene expression in ventricles of rats with spontaneous biventricular hypertrophy. J. Clin. Invest. 81:431-434.

34. Nickerson, P. A., and R. M. Conran. 1981. Parathyroidectomy ameliorates vascular lesions induced by deoxycorticosterone in rat. Am. J. Pathol. 105:185-190.

35. Nickerson, P. A. 1984. A low dose of calcium antagonist (Nitrendipine) ameliorates cardiac and renal lesions induced by DOC in the rat. Exp. Mol. Pathol. 41:309-320.

36. Bishop, S. P., and L. R. Melsen. 1976. Myocardial necrosis, fibrosis and DNA synthesis in experimental cardiac hypertrophy induced by sudden pressure overload. Circ. Res. 39:238-245.

37. Bartosová, D., M. Chvapil, B., Korecký, O. Poupa, K. Rakusan, Z. Turek, and M. Vizek. 1969. The growth of the muscular and collagenous parts of the rat heart in various forms of cardiomegaly. J. Physiol. (Lond.). 200:285-29531.

38. Sap, J., A. Muñoz, K. Damm, Y. Goldberg, J. Ghysdael, A. Leutz, H. Beug, and B. Vennström. 1986. The c-erb-A protein is a high-affinity receptor for thyroid hormone. Nature (Lond.). 324:635-640.

39. Izumo, S., and V. Mahdavi. 1988. Thyroid hormone receptor $\alpha$ isoforms generated by alternative splicing differentially activate myosin $\mathrm{HC}$ gene transcription. Nature (Lond.). 334:539-542.

40. Murata, Y., H. Seo, K. Sekiguchi, T. Imai, J. Lee, and N. Matsui. 1990. Specific induction of fibronectin gene in rat liver by thyroid hormone. $\mathrm{Mol}$. Endocrinol. 4:693-699.

41. Watzke, H., H. P. Schwartz, and M. Weissel. 1987. Fibronectin during thyroid hormone replacement therapy. Thromb. Res. 46:347-353.

42. Everett, A. W., W. A. Clark, R. A. Chizzonite, and R. Zak. 1983. Changes in synthesis rates of $\alpha$-and $\beta$-myosin heavy chains in rabbit heart after treatment with thyroid hormone. J. Biol. Chem. 258:2421-2425.
43. Izumo, S., A. M. Lompré, R. Matsuoka, G. Koren, K. Schwartz, B. NadalGinard, and V. Mahdavi. 1987. Myosin heavy chain messenger RNA and protein isoform transitions during cardiac hypertrophy. J. Clin. Invest. 79:970-977.

44. Nagai, R., A. Herzberg-Zarain, C. J. Brandl, J. Fujii, M. Tada, D. H. MacLennan, N. R. Alpert, and M. Periasamy. 1989. Regulation of myocardial $\mathrm{Ca}^{2+}$-ATPase and phospholamban mRNA expression in response to pressure overload and thyroid hormone. Proc. Natl. Acad. Sci. USA 86:2966-2970.

45. Winegrad, S., C. Wisnewsky, and K. Schwartz. 1990. Effects of thyroid hormone on accumulation of mRNA for skeletal and cardiac $\alpha$-actin in hearts from normal and hypophysectomized rats. Proc. Natl. Acad. Sci. USA 87:24562460.

46. Hynes, R. O. 1990. In Fibronectins. Springer-Verlag, New York. 318319.

47. Guan, Jun-Li., J. E. Trevithick, and R. O. Hynes. 1990. Retroviral expression of alternatively spliced froms of fibronectin. J. Cell Biol. 110:833-847.

48. French-Constant, C., and R. O. Hynes. 1989. Alternatively splicing of fibronectin is temporally and spatially regulated in the chick embryo. Development. 106:375-388.

49. French-Constant, C., L. Van De Water, H. F. Dvorak, and R. O. Hynes. 1989. Reappearance of an embryonic pattern of fibronectin splicing during wound healing in the adult rat. J. Cell Biol. 109:903-914.

50. Izumo, S., B. Nadal-Ginard, and V. Mahdavi. 1988. Protooncogene induction and reprogramming of cardiac gene expression produced by pressure overload. Proc. Natl. Acad. Sci. USA 85:339-343.

51. Gustafson, T. A., B. E. Markham, J. J. Bahl, and E. Morkin. 1987. Thyroid hormone regulates expression of a transfected $\alpha$-myosin heavy-chain fusion gene in fetal rat hearts. Proc. Natl. Acad. Sci. USA 84:3122-3126.

52. Long, C. S., C. P. Ordahl, and P. C. Simpson. 1989. $\alpha$-Adrenergic receptor stimulation of sarcomeric actin isogene transcription in hypertrophy of cultured rat heart muscle cells. J. Clin. Invest. 83:1078-1082.

53. Schwartz, K., D. de la Bastie, P. Bouveret, P. Oliveiro, S. Alonso, and M. Buckingham. 1986. $\alpha$-Skeletal muscle actin mRNAs accumulate in hypertrophied adult rat hearts. Circ. Res. 59:551-555.

54. Komuro, I., T. Kaida, Y. Shibazaki, M. Kurabayashi, Y. Katoh, E. Hoh, F. Takaku, and Y. Yazaki. 1990. Stretching cardiac myocytes stimulates protooncogene expression. J. Biol. Chem. 265:3595-3598.

55. Mardi, J. A., M. A. Reidy, O. Kocher, and L. Bell. 1989. Endothelial cell behavior after denudation injury is modulated by transforming growth factor- $\beta 1$ and fibronectin. Lab. Invest. 60:755-765.

56. Blatti, S. P., D. N. Foster, G. Ranganathan, H. L. Moses, and M. J. Getz. 1988. Induction of fibronectin gene transcription and mRNA is a primary response to growth-factor stimulation of AKR-2B cells. Proc. Natl. Acad. Sci. USA 85:1119-1123.

57. Dean, D. C., R. F. Newby, and S. Bourgeois. 1988. Regulation of fibronectin biosynthesis by dexamethasone, transforming growth factor $\beta$, and cAMP in human cell lines. J. Cell Biol. 106:2159-2170. 